\title{
Cassava, Plantain and Moringa Grown in an Alfisol and their Resilience to Bush Fire in Eastern Nigeria
}

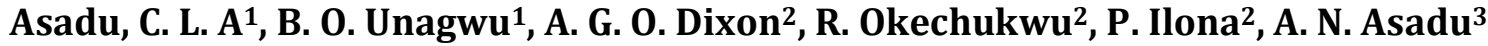 \\ 1Department of Soil Science, University of Nigeria, Nsukka (UNN) \\ 2International Institute of Tropical Agriculture (IITA), Ibadan, Nigeria \\ 3Department of Agricultural Extension, University of Nigeria, Nsukka (UNN)
}

\begin{abstract}
How to cite this paper: Asadu, C. L. A I B. 0. Unagwu | A. G. O. Dixon | R. Okechukwu | P. Ilona | A. N. Asadu "Cassava, Plantain and Moringa Grown in an Alfisol and their Resilience to Bush Fire in Eastern Nigeria" Published in International Journal of Trend in Scientific Research and Development (ijtsrd), ISSN: 24566470, Volume-3 | Issue-3, April 2019, pp. 74-78. http://www.ijtsrd.co $\mathrm{m} /$ papers/ijtsrd216 64.pdf

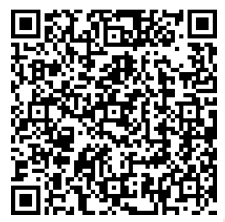
IITSRD21664
\end{abstract}

Copyright (C) 2019 by author(s) and International Journal of Trend in Scientific Research and Development Journal. This is an Open Access article distributed under the terms of the Creative Commons

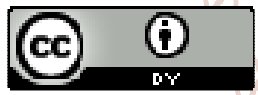
Attribution License (CC BY 4.0) (http://creativecommons.org/licenses/ by/4.0)

\section{INTRODUCTION}

Cassava (Manihot esculenta) is well known for its cash and food security values (Nweke et al, 2002). Cassava is also known as manioc, yucca, madioca, macaxereia and Brazilian arrowroot. It originated from South America. Currently, Nigeria is the largest producer in the world. Southeastern Nigeria is known for cassava production. The food security value of cassava is associated with its advantages over most crops. This is because cassava tolerates pest and disease attack, fire and draught; serves as a cheap source of carbohydrate; has flexible time of planting and harvesting; and has high soil storage value ${ }^{1,2}$. Specifically, cassava is generally known as a food security crop satisfying the calorific needs of roughly two out of every Africans and more than $65 \%$ of the calorific energy needs of the people of subSaharan Africa including Nigeria².

During many field studies including the Collaborative Study of Cassava in Africa (COSCA) study, several burnt cassava fields were observed. Information on the resistance of cassava to fire is scanty, possibly because researchers would not ordinarily set their farms on fire so as to assess the impact of fire on his experiment. The COSCA showed that in
Sub-Saharan Africa (SSA), the number of cassava farms set on fire during the dry season by hunters of bush animals is high and wide spread ${ }^{3}$. Most times, the commonest reports by farmers often centred on cassava stems burnt and rendered useless. However, there is scarce information on the effect of fire on the cassava root yields and shoot (stems and leaves) regeneration.

Plantain is a major staple food in Africa, Latin America, and Asia. Four African countries have the highest per capita consumption of banana/plantain in the world, with Uganda having the highest. Plantain provides food security and income for small-scale farmers who engage in its production 4 . Plantain is cherished in eastern Nigeria for its food and cash values.

Both the soil fertility restoration ${ }^{5}$ and medicinal values of moringa have been documented ${ }^{6}$. Moringa oleifera is a fastgrowing tree native to South Asia and now found throughout the tropics 7 . It is sometimes described as the "miracle tree", "drumstick tree", or "horse-radish" tree because of its health and agricultural uses. Moringa extract can be used as a liquid fertilizer. The ratio of moringa extract to water should be 
1:30 when used as a liquid fertilizer. To attain the maximum yield of most crops, the dilution can be used as the best foliar applicator to enhance yield because the extract is rich in NPK along with other nutrients and trace minerals. Moringa leaf extract applied on the crops does not harm bees, wasps and butter-flies but helps to control all other pests even rodents?. Cassava + plantain + Moringa intercrop has been identified as possible alternative cropping system that can improve and sustain the income of smallholder farmers in eastern Nigeria ${ }^{5}$.

Southeastern Nigeria is known for cassava production. In February 2018, barely ten months after planting, onehectare cassava + plantain + moringa alley farm established at the University of Nigeria, Nsukka Teaching Farm which involved two popular improved IITA cassava varieties grown by the local farmers (IITA-TMS-IBA070539) also known as yellow root) and (TMS 30572 also known as 'Agric' was set on fire by unknown person at the peak of dry season. This fire outbreak necessitated the need to evaluate the effect of such bush fire on crop resilience vis- $a$-vis plant survival rate, regrowth and yield potentials. This study compared the resilience of cassava, moringa and plantain to bush fire and the superiority of two cassava varieties involved in the fire incidence. The yellow variety has a pro-vitamin A content that averages 10 parts per million (ppm) based on fresh roots $^{8}$.

\section{MATERIALS AND METHODS \\ 2.1 Location of the Study}

Nsukka is located by latitude $06052^{\prime} \mathrm{N}$, longitude $07024^{\prime} \mathrm{E}$ within the derived savanna zone of Eastern Nigerian. The average elevation of Nsukka area is $447 \mathrm{~m}$ above sea level. The area is dominated by two seasons namely the rainy and the dry seasons. The former lasts from April to October with a short break (August Break) normally in the month of August. Average annual rainfall is about $1550 \mathrm{~mm}$ and more than $85 \%$ of this rain falls within the rainy season. The average minimum and maximum temperatures are about 22 and $30{ }^{\circ} \mathrm{C}$ respectively while the average relative humility is rarely below $60 \%{ }^{9}$. The soil was formed from the residua of false-bedded sandstone and has been classified as Rhodic Kandustalf (Haplic Lixisol). Nsukka location meets the biophysical requirement for the growth of most tree and arable crops including plantain and moringa ${ }^{10}$.

\subsection{Field establishment}

The field was ploughed, harrowed by tractor, and then alleys of plantain and moringa were established at $5 \mathrm{~m}$ apart and 6 $\mathrm{m}$ along the alleys in May 2017. Plantain was planted at $9 \mathrm{~m}$ apart and moringa was planted in-between the plantain stands giving a plant population of 1111 plants ha-1. Ridges were made by tractor between the alleys and two improved IITA cassava varieties TMS 30572 known as "Agric" and IITA-TMS-IBA070539, known as "Yellow root", in the study area, were planted at $0.5 \mathrm{~m}$ by $1 \mathrm{~m}$ giving a plant population of 20000 plants ha-1 (Plate 1). Poultry manure was broadcast at the rate of $8 \mathrm{t} \mathrm{ha}^{-1}$ on the harrowed plots before ridging. Again, poultry manure was also applied to the plantain at $0.5 \mathrm{~kg}$ stand $\mathrm{d}^{-1}$. Both rates approximate farmers' practice in the area. The two cassava varieties were arranged in a completely randomized block design (RCBD) replicated three times. In the second week of February $2018, \approx 10$ months after planting, the entire field was burnt by unknown persons (Plate 2). The burning was facilitated by the undergrowth of dry grass and dry portions of the crops.

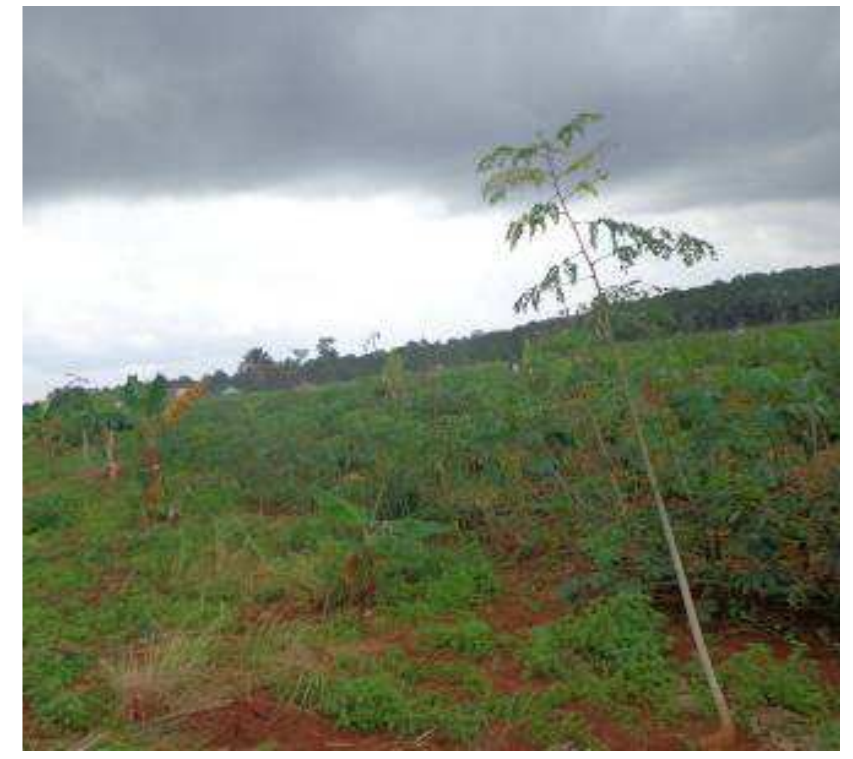

Plate1: Moringa and plantain planted in one row along one alley and cassava in the next alley

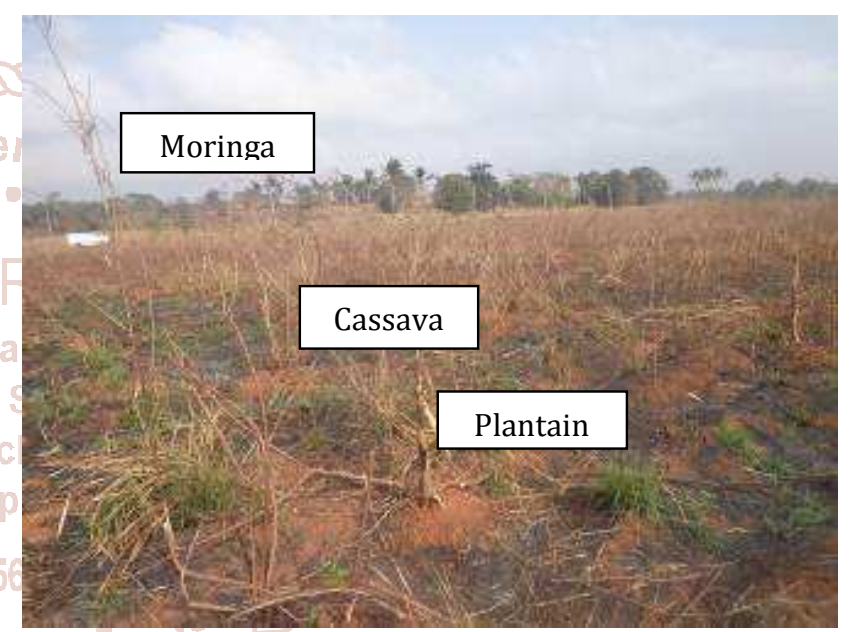

Plate2. Burnt field of the Cassava + Plantain + Moringa at UNN in February 2018

2.3 Survival Count of Cassava, Plantain and Moringa The numbers of cassava, plantain and moringa regenerated from their burnt stands across the entire field were taken. Photograph of the regenerated shoots were also captured. These activities were carried out in the first week of July 2018 approximately six months after burning (6 MAB).

\subsection{Cassava Sampling}

From the three replicates of cassava plots, three subplots measuring $5 \mathrm{~m} \times 6 \mathrm{~m}$ were carved out for data collection. The following data were taken: number of regenerated cassava stands, weight of cassava leaves, weight of plantable stems, weight of fresh roots, weight of marketable roots and unmarketable roots as well as that of rotten roots. The starch contents of the fresh roots of the two cassava varieties were evaluated in the field using the specific gravity method ${ }^{11}$. The set up is shown as Plate 3 . The following parameters were obtained:

$\mathrm{W}_{\mathrm{o}}=$ weight of the cassava sample in air

$\mathrm{W}_{\mathrm{u}}=$ weight of the sample under water

$\mathrm{Sg}=$ specific gravity

$\mathrm{BC}=$ basket compensated weight

(BC = weight in air - weight under water) 
then

$\mathrm{Sg}=\mathrm{Wo} / \mathrm{W}_{\mathrm{o}}-\left(\mathrm{W}_{\mathrm{u}}+\mathrm{BC}\right)$

Starch content $=(\mathrm{Sg}-1.00906) / 0.004845 \%$

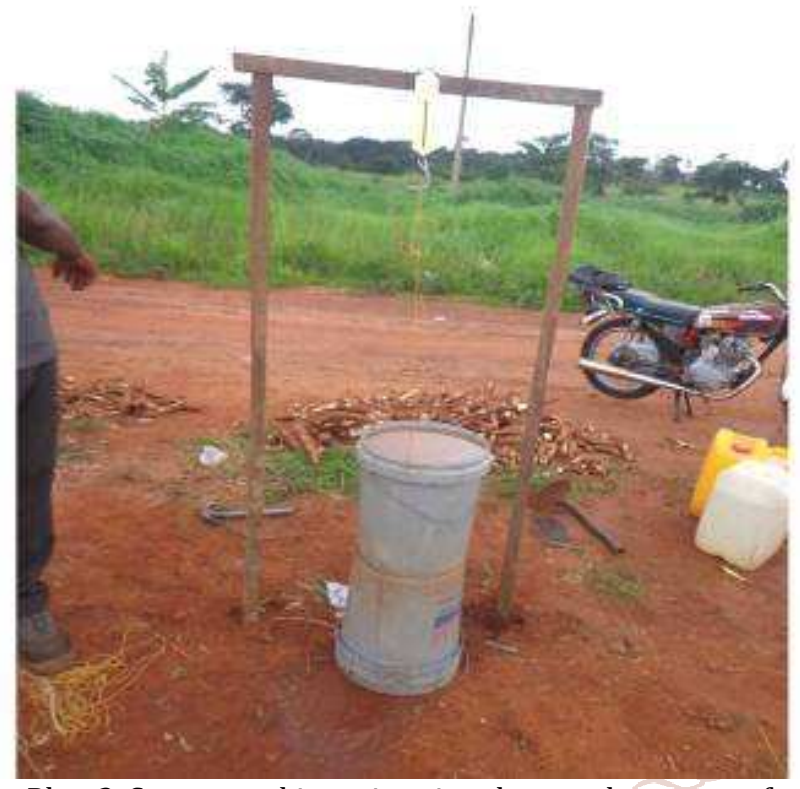

Plate3. Set up used in estimating the starch content of Scie fresh root of cassava in the field

\subsection{Sorting of Cassava Parameters}

\subsubsection{Marketable and unmarketable fresh roots}

Generally, in Nigeria, cassava markets are bound both in rural and semi-urban areas. Sorted cassava tubers have premium price across cassava markets Thus, the weight or number of marketable roots is more relevant than entire fresh root yield (unsorted harvest).

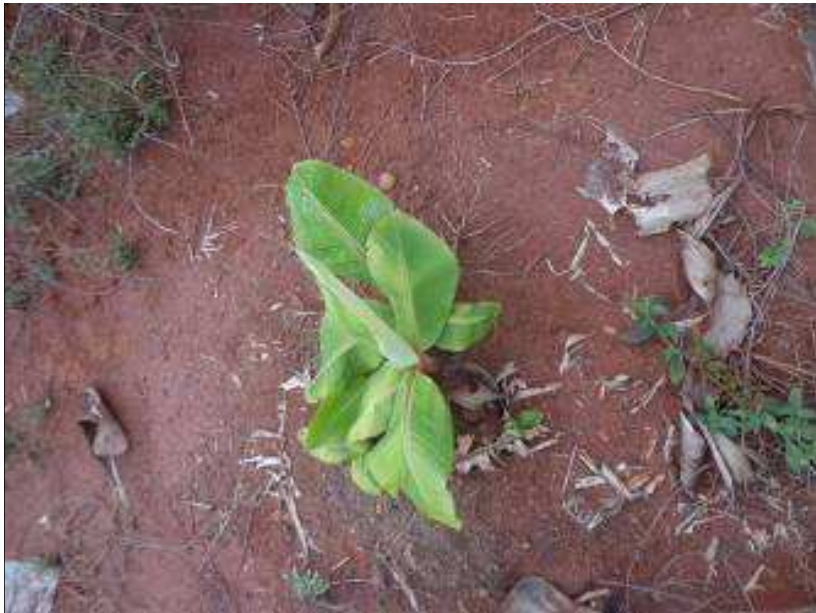

Plate4: Impoverished regenerated plantain stand at $6 \mathrm{MAB}$

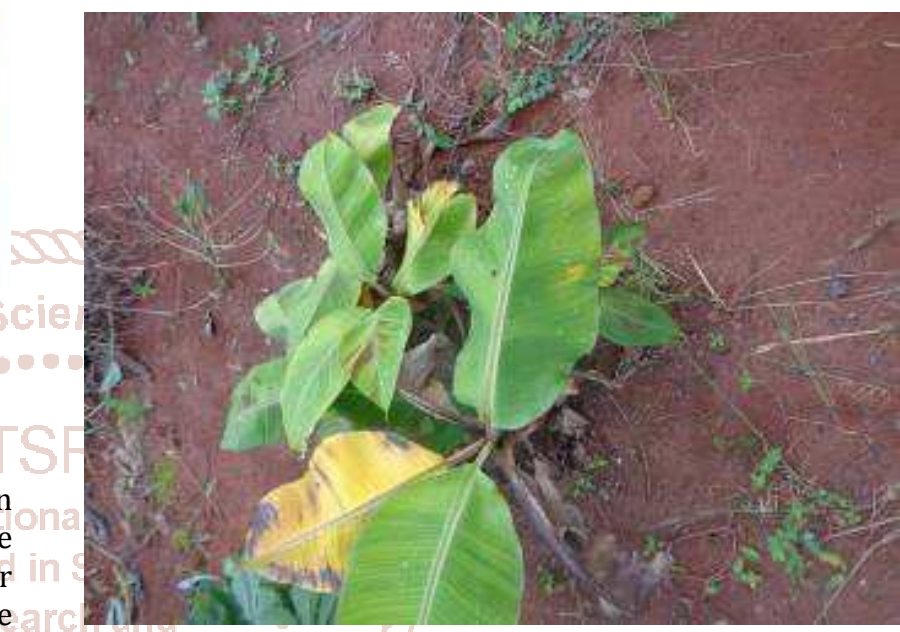

Plate 5: Another two impoverished regenerated plantain Development stands from the same spot at 6 MAB

Marketable roots have been defined ${ }^{12}$ as those roots which are at least $15 \mathrm{~cm}$ in length. However, we considered those roots that cannot be held in the hand while peeling $(<10 \mathrm{~cm}$ in length) as unmarketable roots based on agricultural extension information and local market experience in Nigeria. Such roots are not, however, useless as they are crushed and fed to animals by the farmers.

\subsubsection{Plantable stems}

Plantable stems are those stems from which at least two viable cuttings of $15 \mathrm{~cm}$ long can be obtained before getting to green part of cassava stem. The green parts of cassava stem hardly survive when the soil is either dry or wet.

\subsubsection{Rotten roots}

The rotten roots were sorted and separated from fresh roots and weighed separately.

\section{RESULTS AND DISCUSSION}

\subsection{Effects of Fire on Crop Survival}

The status of the field when the farm was burnt in February 2018 is shown Plate 2. The entire field appeared charred with no hope of any crop re-growing. The number of plantain that regenerated at $6 \mathrm{MAB}$ was $<5 \%$ of the original stands (Table 1) and the regenerated stands appeared very impoverished (Plate 4and 5) as compared with the plantain stand at the edge of field not affected by fire (Plate 6).

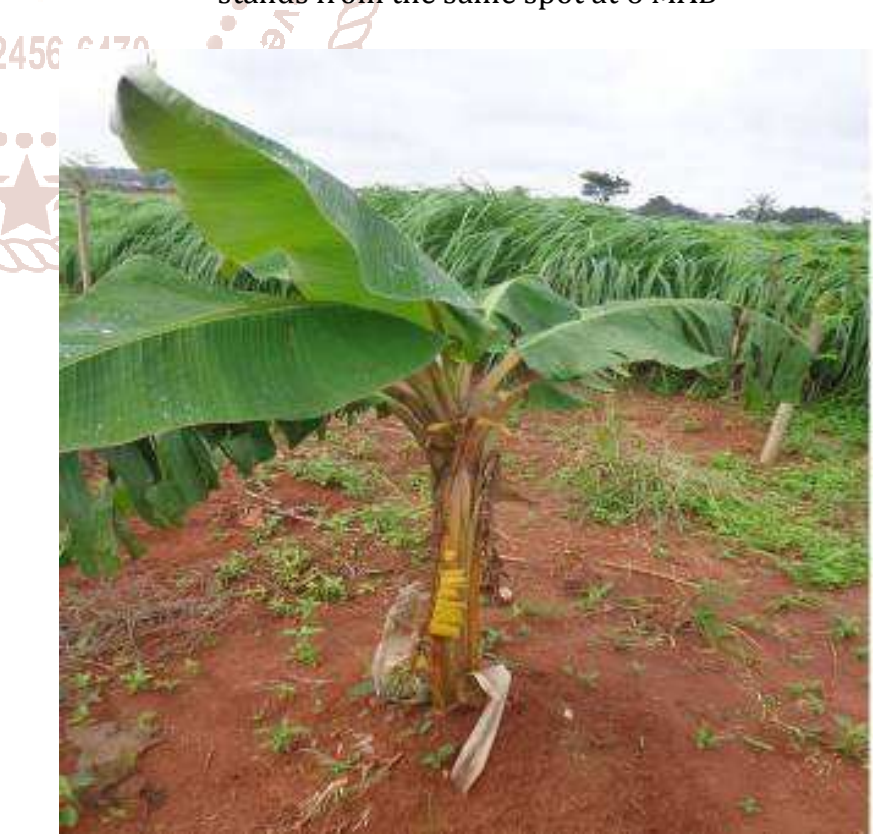

Plate6. Plantain stand at the edge of field not affected by fire

The effect of fire appeared worse on moringa than on plantain. This was evident by $<4 \%$ of the original stands of moringa that was counted at $6 \mathrm{MAB}$ (Table 1). The moringa stands also appeared impoverished (Plate 7). 


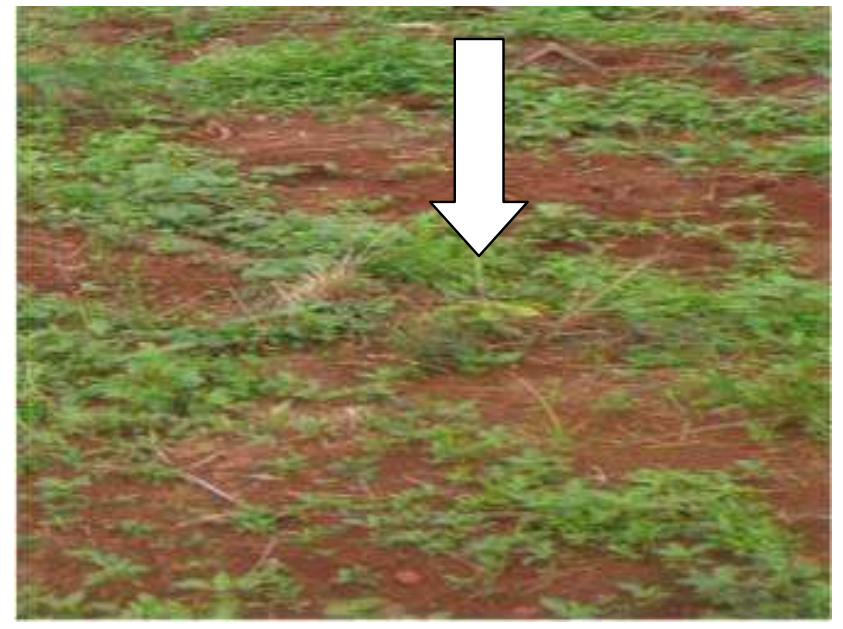

Plate 7. Impoverished regenerated moringa stand at 6 MAB

In contrast, the mean number of cassava stands counted at 6 MAB was $>90 \%$ (Table 2) and the cassava stands looked well nourished (Plates 8 and 9).

The results clearly showed the superiority of cassava over plantain and moringa when subjected to bush fire. This resistance to fire agrees with established facts that cassava is a reliable food security crop ${ }^{3,1}$. It also raises the hope of cassava farmers whose farms are subjected to frequent bush fire by hunters of bush animals.

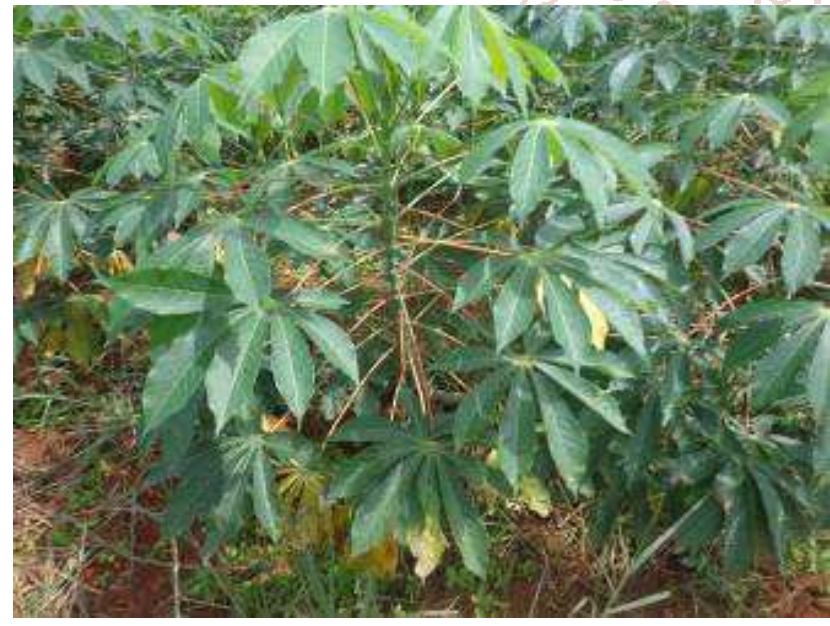

Plate 8: Flourishing Yellow root at $6 \mathrm{MAB}$

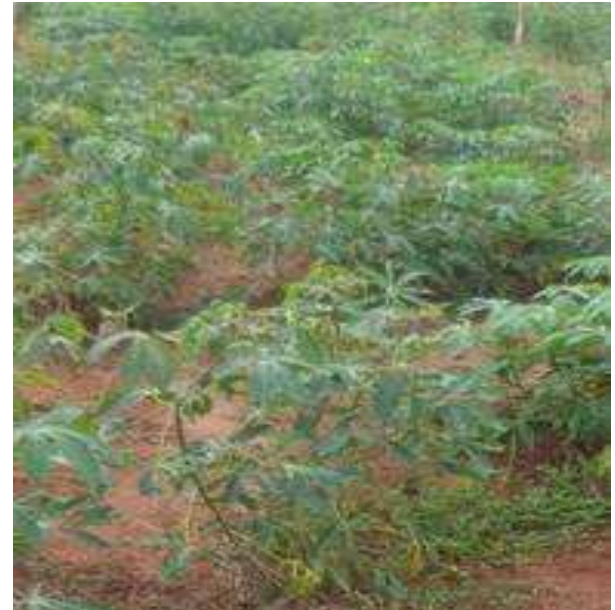

Plate 9: Flourishing TMS 39572 (Agric) at 6 MAB

\subsection{Comparison of the Resilience of Two IITA Cassava Varieties to Bush Fire}

The data obtained showed that the two cassava varieties (Agric and Yellow root) did not differ significantly in the number of stands regenerated at $6 \mathrm{MAB}$ (Table 1). Similarly, cassava stem, leaf and shoot (above-ground biomass) weights; and root: shoot ratios associated with the two varieties did not differ significantly. Although the root weights of "Agric" and "Yellow root" varieties were statistically the same, "Yellow root" had 38\% higher average root weight than "Agric" variety. The non-significant differences in the parameters obtained from the two varieties at $6 \mathrm{MAB}$ suggest that both varieties have similar genetic potentials to resist fire. However, the starch content obtained from "Yellow root" variety was significantly higher than that obtained from "Agric" by 36\%. The significant difference in the starch content obtained could be attributed to the variance associated with their inherent genetic makeup indicating that Yellow root was superior to Agric with respect to starch content at 6 MAB. Possibly the fortification of "Yellow root" with pro-vitamin A content that averages 10 parts per million (ppm) based on fresh roots ${ }^{4}$. (IITA, 2014) may be responsible for the observed differences in the starch content. This result requires further investigation.

The average rotten root percentages for "Yellow root" and "Agric" were 5\% and 3\% respectively and when compared statistically there was no difference. This is another advantage of the varieties. It is, however, possible that the bush fire killed the microbial organisms that would have contributed to the rotting of the roots and the organisms could not repopulate before July when root harvesting was carried out. This is another area of research challenge because the expectation would be that a lot of the roots would have been rotten at $6 \mathrm{MAB}$ the heat from the fire.

Table 1 Effect of bush fire on cassava some re-growth parameters and starch content of two cassava varieties

\begin{tabular}{|c|c|c|c|c|c|c|c|}
\hline Variety & $\begin{array}{c}\text { Number } \\
\text { of stands } \\
\left(\text { ha }^{-1}\right)\end{array}$ & $\begin{array}{c}\text { Stem } \\
\text { weight } \\
\left(\mathrm{t} \mathrm{ha}^{-1}\right)\end{array}$ & $\begin{array}{c}\text { Leaf } \\
\text { weight } \\
\left(\mathbf{t ~ h a}^{-1}\right)\end{array}$ & $\begin{array}{c}\text { Shoot } \\
\text { weight } \\
\left(\mathbf{t ~ h a}^{-1}\right)\end{array}$ & $\begin{array}{c}\text { Root } \\
\text { weight } \\
\left(\mathbf{t ~ h a}^{-1}\right)\end{array}$ & $\begin{array}{c}\text { root: } \\
\text { shoot } \\
\text { ratio }\end{array}$ & $\begin{array}{c}\text { Starch } \\
\text { content (\%) }\end{array}$ \\
\hline Agric & 14333 & 4.67 & 4.28 & 8.94 & 14.5 & 3.35 & 19.7 \\
\hline Yellow root & 15100 & 4.44 & 5.28 & 9.72 & 22.8 & 5.28 & 30.9 \\
\hline LSD & NS & NS & NS & NS & NS & NS & 6.0 \\
\hline
\end{tabular}

Similarly, the number and weight of marketable and unmarketable cassava roots associated with the two varieties did not differ significantly (Table 2). Plate 10 shows cassava fresh roots sorted into marketable and unmarketable categories. 
Table 2 Effect of bush fire on cassava re-grown plantable stems, marketable and unmarketable number, marketable and unmarketable plant weight of two cassava varieties

\begin{tabular}{|c|c|c|c|c|c|}
\hline & $\begin{array}{c}\text { Number of } \\
\text { plantable } \\
\text { stems (ha-1) }\end{array}$ & $\begin{array}{c}\text { Marketable } \\
\text { weight of } \\
\text { roots (t ha-1 })\end{array}$ & $\begin{array}{c}\text { Marketable } \\
\text { Number } \\
\text { of roots ( ha-1) }\end{array}$ & $\begin{array}{c}\text { Unmarketable } \\
\text { Weight of } \\
\text { Roots }\left(\mathrm{t} \mathrm{ha}^{-1}\right)\end{array}$ & $\begin{array}{c}\text { Unmarketable } \\
\text { Number of } \\
\text { roots (ha-1) }\end{array}$ \\
\hline Agric & 33667 & 13.7 & 58333 & 0.78 & 15567 \\
\hline Yellow root & 40000 & 21.6 & 54000 & 1.22 & 18567 \\
\hline LSD & NS & NS & NS & NS & NS \\
\hline
\end{tabular}

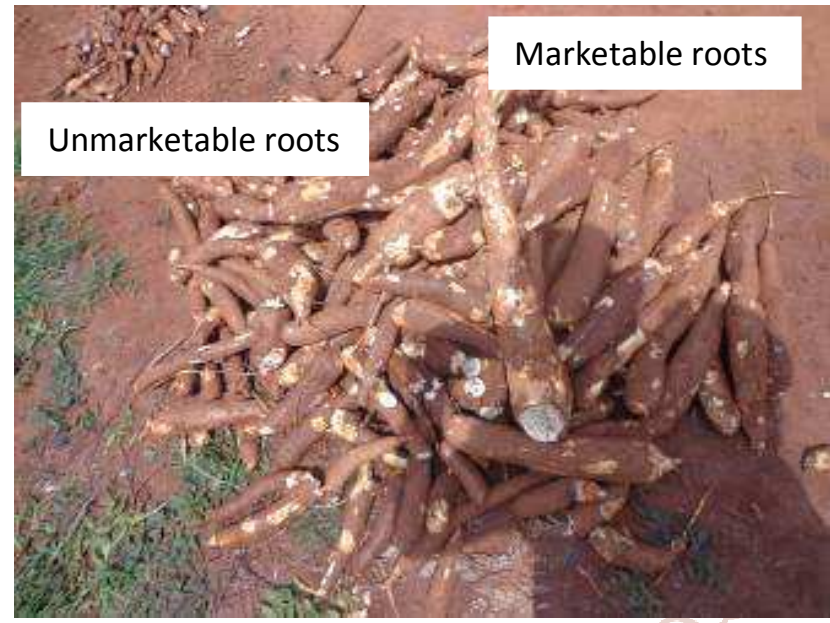

Plate10. Cassava sorted into unmarketable and marketable fresh roots categories at $6 \mathrm{MAB}$

\section{CONCLUSION}

The effect of bush fire on plantain, moringa and cassava from this evaluation was more disastrous on both plantain and moringa than on cassava. The effects of bush fire on the regrowth parameters of the two improved cassava varieties, IITA-TMS-IBA070539 (Yellow Root) and TMS 30572 (Agric) namely: number of regenerated stands, plantable and unplantable stems, weight of stems and fresh roots, rotten roots, marketable and unmarketable fresh roots were similar. The starch content of "Yellow root" was significantly higher than that of "Agric". The resistance of cassava to bush fire confirms cassava as a better food security crop than plantain and more resilient to fire than both plantain and moringa. The two IITA improved varieties proved to be equally resilient to bush fire. This additional attribute of cassava raises the hope of cassava farmers whose farms are often subjected to seasonal bush fire in sub-Saharan Africa and confirms cassava as a reliable food security crop.

\section{REFERENCES}

[1] Asadu, C.L.A. and F.I. Nweke. 1999. The soils of cassavagrowing areas in sub- Saharan Africa. COSCA Working Paper No 18. Collaborative Study of Cassava in Africa. RCMD, International Institute of Tropical Agriculture (IITA), Ibadan, Nigeria.199pp..

[2] Nweke, F.I., Spencer, D.S.C. and J.K. Lynam. 2002. The cassava Transformation, Africa's best-kept secret. International Institute of Tropical Agriculture (IITA), Ibadan, Nigeria. 273pp

[3] Nweke, F.I., B.O.Ugwu, A.G.O. Dixon, C. L. A. Asadu and O. Ajobo. 1999. Cassava Production in Nigeria: A function of Farmer Access to Markets and to Improved Production and Processing Technologies. COSCA Working Paper No.20.Collaborative Study of Cassava in Africa, IITA, Ibadan, Nigeria.

[4] International Institute of Tropical Agriculture, IITA. 2016. Banana \& Plantain. Retrieved November 2, 2016, from http://www.iita.org/banana-and-plantain.

[5] Ndubuaku, U.M. and I.N. Dimelu. 2011. Moringa dishes and products in Southeastern Nigeria. University of Nigeria Press, Nsukka. 29pp.

[6] Mercola, J. 2015. The many uses of the mighty moringa tree. Retrieved from http://wakeupworld.com/2015/09/19/the-many-uses-of-themighty-moringa-tree

[7] Asadu, C. L. A. 2016. Sustaining Biodiversity and Income against Climate Change through Food Value Chain System by the Small-Holder Farmers in Southern Nigeria. Path of Science, [S.l.], v. 2, n. 11, p. 8.1-8.7, Nov 2016. ISSN 2413-9009. Available at: <http://pathofscience.org/index.php/ps/article/view/ 258>. Date accessed: 06 December. 2016. doi: http://dx.doi.org/10.22178/pos.16-9.

[8] International Institute of Tropical Agriculture, (IITA). 2014. Nigeria releases more cassava with higher provitamin A to fight micronutrient deficiency IITA News and Events: http://www.iita.org/news-item/nigeriareleases-cassava-higher-pro-vitamin-fight-

micronutrient-deficiency/6 July 2014

[9] Asadu, C. L.A. 2002. Fluctuations in the characteristics of an important short tropical season, 'august break' in Eastern Nigeria. Discovery and Innovation, 14(1), 92101.

[10] National Horticultural Research Institute (NHRI). 2016. Cropping systems with Plantain/Banana in Nigeria. Retrieved from http://banana-networks.org/innovateplantain/files/2013/11/2_presentation-NIGERIA.pdf

[11] Sungzikaw, S. 2008. Determination of starch content of fresh root of cassava by the specific gravity method. Workshop on Metrology in Food Safety, Agricultural Products and Product Safety, Hangzhou, PR China, June 2-6, 2008.

[12] Tan, S. L. and M. Normah 1995. A comparison of cassava (Manihot esculenta Crantz) varieties Perintis and MM 92 in relation to cropping duration and soil type [Perbandingan antara varieti ubi kayu (Manihot esculenta Crantz) Perintis dan MM 92 berkaitan dengantempoh penanaman dan jenis tanah], Malaysian Agricultural Research and Development Institute (MARDI) Res. J. 23(2) 103-113 